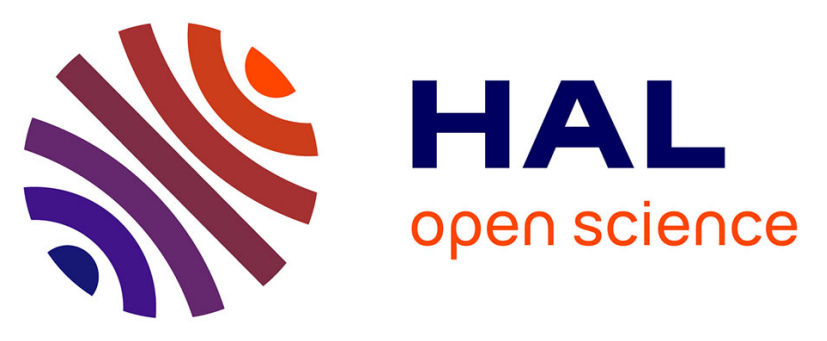

\title{
Enhanced 5-fluorouracil cytotoxicity in high cyclooxygenase-2 expressing colorectal cancer cells and xenografts induced by non-steroidal anti-inflammatory drugs via downregulation of dihydropyrimidine dehydrogenase
}

Andrea Réti, Éva Pap, Vilmos Adleff, András Jeney, Judit Kralovánszky, Barna Budai

\section{- To cite this version:}

Andrea Réti, Éva Pap, Vilmos Adleff, András Jeney, Judit Kralovánszky, et al.. Enhanced 5fluorouracil cytotoxicity in high cyclooxygenase-2 expressing colorectal cancer cells and xenografts induced by non-steroidal anti-inflammatory drugs via downregulation of dihydropyrimidine dehydrogenase. Cancer Chemotherapy and Pharmacology, 2009, 66 (2), pp.219-227. 10.1007/s00280-0091149-8 . hal-00568273

\section{HAL Id: hal-00568273 \\ https://hal.science/hal-00568273}

Submitted on 23 Feb 2011

HAL is a multi-disciplinary open access archive for the deposit and dissemination of scientific research documents, whether they are published or not. The documents may come from teaching and research institutions in France or abroad, or from public or private research centers.
L'archive ouverte pluridisciplinaire HAL, est destinée au dépôt et à la diffusion de documents scientifiques de niveau recherche, publiés ou non, émanant des établissements d'enseignement et de recherche français ou étrangers, des laboratoires publics ou privés. 
Enhanced 5-fluorouracil cytotoxicity in high cyclooxygenase-2 expressing colorectal cancer cells and xenografts induced by non-steroidal anti-inflammatory drugs via downregulation of dihydropy rimidine dehydrogenase

Andrea Réti ${ }^{1}$, Éva Pap ${ }^{1}$, Vilmos Adleff ${ }^{1}$, András Jeney, ${ }^{2}$ Judit Kralovánszky ${ }^{1}$, Barna Budai 1

${ }^{1}$ National Institute of Oncology;

$21^{\text {st }}$ Institute of Pathology and Experimental Cancer Research, Semmelweis University; Budapest, Hungary

Dr. Judit Kralovánszky

Phone: 36-1-224 8787

Fax: 36-1-224-8787

E-mail:kralo@oncol.hu

Keywords: indomethacin, NS-398, 5-fluorouracil, cyclooxygenase-2, dihydropyrimidine dehydrogenase 


\section{Abstract}

Purpose: To prove that 5-FU cytotoxicity could be increased by combination with low-dose non-steroidal anti-inflammatory drugs (NSAIDs) (indomethacin or NS-398) in high cyclooxygenase-2- (COX-2) expressing cells and xenografts through the modulation of dihydropyrimidine dehydrogenase (DPD) mRNA expression and/or enzyme activity.

Methods: HT-29 cells were grown on collagen IV coated plates. (HT-29-C). The antiproliferative effect of 5-fluorouracil (5-FU) \pm NSAIDs was examined on non-COX-2 expressing HT-29 and COX-2-expressing HT-29-C cells by sulphorhodamine B assay. The COX-2 and DPD expressions were visualized by immunofluorescent staining, and prostagland in $\mathrm{E}_{2}$ levels were measured by ELISA kit. The HT-29 xenograft was established in SCID mice and treated with 5-FU \pm NSAIDs for 5 days. The tumor volume, DPD mRNA expression and enzyme activity were investigated by calliper, radioenzymatic method and real-time RT-PCR, respectively. The drug interaction was calculated for both combinations (5-FU+indomethacin and 5-FU+NS-398).

Results: Collagen IV up-regulated significantly the COX-2 and DPD mRNA and protein expressions and also their enzyme activities in HT-29 cells. NSAIDs enhanced in a synergistic manner the cytotoxic effect of 5-FU treatment both in vitro and in vivo. Downregulation of DPD was observed after 5-FU monotherapy, but the combined effect of NSAIDs and 5-FU on DPD mRNA expression and enzyme activity was superior to the effect of 5-FU alone.

Conclusions: Since 5-FU+NSAID treatment can alter the DPD enzyme activity resulting in an enhanced cytotoxic effect further studies in clinical practice are varranted. 


\section{Introduction}

One of the most widely used anticancer agents for treatment of colorectal cancer is 5-FU. The rate-limiting enzyme of 5-FU catabolism is dihydropyrimidine dehydrogenase (DPD). Besides the liver and the peripheral mononuclear cells, tumoral DPD has become of clinical interest because elevated intratumoral DPD can decrease the tumor response to 5-FU therapy since more than $80 \%$ of the administered 5-FU is catabolised in vivo by DPD to 5,6-dihydro5-fluorouracil. The degradation of 5-FU reduces its efficiency and requires extremely high doses and the fluorinated products may cause side-effects in the nervous system [1].

In order to improve the effectiveness of 5-FU, a new subclass of orally administrated fluoropyrimidines, UFT and S1, containing potent DPD inhibitors, i.e: uracil and 5-chloro-2,4 dihydroxypyridine (CDHP), respectively, were developed [2]. An irreversible inhibitor of DPD, ethynyluracil, was also studied and found to be effective in clinical trials [3]. Kralovánszky et al. proved that 5-ethyl-2'-deoxyuridine enhanced the therapeutic index of 5FU by reducing its catabolism [4].

Cyclooxygenase-2 (COX-2) is a rate-limiting enzyme in the synthesis of prostanoids and is common in human malignancies, including cancer of the colon. The upregulation of COX-2 promotes tumor cell growth, angiogenesis, tumor invasion and metastasis. Non-steroidal antiinflammatory drugs (NSAIDs) inhibit the COX-2 enzyme activity. Several preclinical and clinical studies have shown that NSAIDs are effective chemopreve ntive and antitumor agents either alone or in combination with standard cancer therapies [5-7]. Previously it was shown that NSAIDs, indomethacin and NS-398, applied in low dose effectively increased the 5fluorouracil (5-FU)-sensitivity in high COX-2 protein-expressing HCA-7 colon cancer cells [8]. In a recent report from our laboratory it was also demonstrated that two NSAIDs: indomethacin and NS-398 in parallel with the COX-2 inhibition decreased also the DPD enzyme activity of high COX-2-expressing HCA-7 cells and HT-29 xenografts. It is 
noteworthy that the HT-29 xenograft was characterized by high COX-2 and DPD enzyme activity after a phenotype change of the implanted low COX-2 and DPD expressing HT-29 cells [9].

To elucidate the possible mechanism of this phenotype change in the present study the HT-29 cells were cultured with extracellular matrix (ECM) components i.e. fibronectin, laminin or collagen IV in order to see if they are able to modify the COX-2 and DPD expression of the cells. Moreover, it was intended to prove whether the 5-FU cytotoxicity could be increased by combination with NSAIDs in the collagen IV-induced HT-29 or in the constitutively high COX-2-expressing HCA-7 cells and in the HT-29 xenografts through the modulation of DPD mRNA expression and/or enzyme activity.

\section{Materials and methods}

\section{Cell lines}

HT-29 and HCA-7 cells were purchased from the European Collection of Cell Cultures (Salisbury, UK) and were cultured in Dulbecco's modified Eagle-medium and RPMI, respectively, supplemented with $10 \%$ (v/v) fetal bovine serum (Sigma-Aldrich, St. Louis, USA).

\section{Coating of plates or glass coverslips}

Six- and 96-well plates or glass coverslips coated with $10 \mu \mathrm{g} / \mathrm{ml}$ human collagen type IV, fibronectin or laminin (Sigma-Aldrich, St. Louis, USA) were incubated for $1 \mathrm{~h}$ at $37^{\circ} \mathrm{C}$ then washed with PBS. The HT-29 cells were seeded on the coated plates and incubated for 4 hours. 
Immunofluorescence staining of COX-2 and DPD proteins

The HT-29 cells were incubated for 4 hours on glass coverslips coated with ECM components. Then cells were fixed in methanol at $-20^{\circ} \mathrm{C}$ for $10 \mathrm{~min}$. and washed twice with PBS. Monolayers were incubated with COX-2 (Cayman Chemicals, Ann Arbor, MI, USA) or DPD (Santa Cruz Biotechnology, Santa Cruz, CA, USA) primary monoclonal antibodies (1:100 and 1:50, respectively) in Superblock Blocking Buffer in TBS for overnight at $4{ }^{\circ} \mathrm{C}$. Following PBS washes monolayers were incubated with the FITC conjugated secondary antibodies (1:1000, respectively) (Alexa Fluor 488, Invitrogen, USA) in Superblock Blocking Buffer in TBS for $2 \mathrm{~h}$ at $4^{\circ} \mathrm{C}$. After further PBS washes the fluorescence was detected by Olympus CKX41 fluorescence microscope (Tokyo, Japan) and documented with Olympus C5060 widezoom camera (Tokyo, Japan).

\section{Prostaglandin $E_{2}$ assay}

The HT-29 cells $\left(1 \times 10^{6}\right)$ in $1 \mathrm{ml}$ culture media were seeded onto non-coated or collagen IV coated wells of 6-well plates. After 4 hours conditioned media were harvested and the concentration of prostaglandin $\left(\mathrm{PGE}_{2}\right)$ was measured by ELIS A (Assay Designs, Ann Arbor, MI, USA) according to the manufacturer's protocol. Measurements were made in triplicate in three separate experiments.

\section{Determination of cell growth inhibition}

The uninduced and collagen-induced HT-29 cells grown in 96-well plates were treated with $10 \mu \mathrm{M}$ 5-FU [8] alone or combined with non selective COX-2 inhibitor, indomethacin (Sigma-Aldrich, St. Louis, USA) or selective COX-2 inhibitor, NS-398 (Cayman Chemicals, Ann Arbor, USA) (10 and $1.77 \mu \mathrm{M}$, respectively) for 8 hours. The sulphorhodamine B (SRB) colorimetric assay was used to determine the cell growth inhibitory effect of the drugs in 96- 
well plates. The detailed SRB assay was described earlier [8]. The experiments were done in six wells of the 96-well plates and repeated three times.

Treatment of collagen-induced HT-29 (HT-29-C) and HCA-7 cells for determination of DPYD mRNA expression and enzyme activity

Collagen-induced HT-29 cells grown in 6-well plates were treated for 8 hours with 5-FU alone or combined with indomethacin or NS-398 as described above. HCA-7 cells grown in 6-well plates were treated with $1 \mathrm{mM} 5$-FU [8] alone or combined with indomethacin or NS398 (10 and $1.77 \mu \mathrm{M}$, respectively) for 24 hours.

\section{Total RNA extraction and cDNA synthesis}

HT-29-C and HCA-7 cells grown in 6-well plates were harvested and total RNA was isolated using RNeasy mini prep kit (Qiagen, Valencia, CA, USA) according to the manufacturer's protocol. The concentration of RNA was determined by measuring the absorbance at $260 \mathrm{~nm}$ with spectrophotometer (BIO-TEK Instruments, VM, USA). Reverse-transcription was performed using RevertAid M-MuLV reverse transcriptase (Fermentas, Glen Burnie, MD, USA). The mRNA templates $(2 \mu \mathrm{g})$ were transcribed with $0.5 \mu \mathrm{g}$ oligo (dT) primer (Fermentas) according to the manufacturer's protocol.

\section{Quantitative real-time $R T$-PCR}

The DPYD and COX-2 mRNA expressions were determined by real time RT-PCR. The $\beta$ actin $(A C T B)$ gene was used as reference. The ACTB primers were: 5'GTGGGGCGCCCCAGGCACCA and 5'-CTCCTTAATGTCACGCACGATTTC. The primers used for amplification of DPYD were: 5'-GAAATGGCCGGATTGAAGTTT and 5'TCGAAGAGCTTTTGAAGCTGG and that for COX-2 were: 5'TTCAAATGAGATTGTGGGAAAATTGCT and 5'-AGTTCATCTCTGCCTGAGTATCTT. 
The amplifications were performed in a mixture of $1 \mu 1 \mathrm{cDNA}, 0.2 \mu 1$ of primers, $5 \mu 1 \mathrm{IQ}$ SybrGreen Supermix (Bio-Rad, Hercules, CA, USA) and $3.6 \mu 1 \mathrm{H}_{2} \mathrm{O}$ on a RotorGene 2000 machine (Corbett Research, Mortlake, Australia). The 3 min denaturation at $95^{\circ} \mathrm{C}$ was followed by 40 cycles of $20 \mathrm{~s}$ denaturation at $95^{\circ} \mathrm{C}, 20 \mathrm{~s}$ annealing at $62^{\circ} \mathrm{C}$ and $30 \mathrm{~s}$ extension at $72^{\circ} \mathrm{C}$. The amplicon purity was checked by melting curve analysis. The relative expression levels were calculated as described by Pfaffl [10]. The results are presented as mean of three experiments.

\section{HT-29 xenografts}

A suspension of $2 \times 10^{6}$ HT-29 cells in physiological saline $(0.1 \mathrm{ml})$ was injected subcutaneously into the hind leg of 6-week-old female SCID mice. All animal experiments were performed according to the ethically approved guidelines of the Animal Care Facility of the $1^{\text {st }}$ Institute of Pathology and Experimental Cancer Research, Semmelweis University, Budapest.

The animal weight $(\mathrm{g})$ and tumor diameters $(\mathrm{mm})$ were measured before the treatment and on the $2^{\text {nd }}, 4^{\text {th }}$ and $6^{\text {th }}$ days with calliper and the tumor volume $\left(\mathrm{mm}^{3}\right)$ was calculated as follows: $\pi \mathrm{x}$ (shortest diameter $)^{2} \mathrm{x}$ (longest diameter)/6.

\section{Treatment of xenograft-bearing mice}

The HT-29 tumor bearing mice were randomly separated into 7 groups, 4 mice each: vehicle control, 6 or $30 \mathrm{mg} / \mathrm{kg} / \mathrm{day} 5-\mathrm{FU}$ and 6 or $30 \mathrm{mg} / \mathrm{kg} / \mathrm{day} 5-\mathrm{FU}+$ indomethacin or NS-398.

The 5-FU (Pharmachemie, Haarlem, Hollandia) was given in two doses: 6 and $30 \mathrm{mg} / \mathrm{kg}$ body weight in $0.2 \mathrm{ml}$ saline and was administered by i.p. injection for 5 days. The applied 30 $\mathrm{mg} / \mathrm{kg} \times 5$ days 5 -FU was regarded as the maximal tolerated dose [11].

The dose of indomethacin and NS-398 was 2.5 and $5 \mathrm{mg} / \mathrm{kg}$, respectively, in $0.2 \mathrm{ml}$ saline and given by oral gavage for 5 days. These doses are qualified as relatively low doses [12, 13]. 
Antitumor activity was evaluated by the change of relative tumor growth (RTG). RTG= (tumor volume on the $6^{\text {th }}$ day - tumor volume before treatment)/tumor volume before treatment.

\section{Measurement of DPD activity}

The DPD enzyme activity of the cells and the xenografts was determined by radioenzymatic method as described previously [8,9]. Measurements were made in parallel in three independent experiments.

\section{Analysis of drug interaction}

The effect of the combination of 5-FU and indomethacin or NS-398 was evaluated according to the method of Kern et al. [14]. The expected cell survival, $\left(S_{\exp }\right)$, defined as the product of the survival observed for 5-FU alone and the survival observed for indomethacin or NS-398 alone: $S_{\text {exp }}=\left(S_{5-\mathrm{FU}}\right) \times\left(S_{\text {indomethacin or NS-398 }}\right)$ and the observed cell survival, $\left(S_{\text {obs }}\right)$, obtained after combination of 5-FU and indomethacin or NS-398 were used to construct a synergistic ratio R $=\mathrm{S}_{\exp } / \mathrm{S}_{\mathrm{obs}}(\mathrm{R})$ defining the drug interaction.. The values are: $\mathrm{R}=1$ additive effect; $>1$, synergistic effect; <1, antagonistic effect.

In case of xenografts the percentage ratio between the tumor volume of treated mice and the tumor volume of controls was used for the Kern's index calculation as described above.

\section{Statistical analysis}

Statistical analyses were performed using GraphPad PRISM software (San Diego, CA, USA). The significance level was determined by analysis of variance (ANOVA) and Tukey's post hoc test. Differences between the collagen-induced and control cells were tested by using Student's t test for paired variants. The $\mathrm{p}$ values $<0.05$ were considered as significant. 


\section{Results}

Expression of COX-2 and DPD in HT-29 cells induced by collagen

In order to verify if the ECM components may induce the COX-2 and DPD expressions, the HT-29 cells were cultured in the presence of collagen IV, fibronectin or laminin. The 4-hour incubation of HT-29 cells on collagen IV, caused significant increase of COX-2 and DPD protein expressions, (Fig. 1) but the fibronectin and laminin treatments were ineffective (data not shown). At the same time the $\mathrm{PGE}_{2}$ level and DPD activities were significantly upregulated as well. DPYD and COX-2 mRNA expressions also showed a 287 and 750 fold increase, respectively, compared to the control cells (Table 1).

Influence of indomethacin or NS-398 on 5-FU cytotoxicity in HT-29, HT-29-C cells

In the uninduced HT-29 cells after 8-hour treatment 5-FU alone caused a very moderate cell growth inhibition which could not be potentiated with NSAIDs.

In HT-29-C cells 5-FU was almost ineffective in growth inhibition, however, the combination of 5-FU with indomethacin or NS-398 resulted in a remarkable growth inhibition (37\% and $41 \%$ inhibition vs control, respectively) (Fig 2.). The potentiation of 5-FU action by NSAIDs was similar to our earlier results obtained in HCA-7 cells, which demonstrated that indomethacin or NS-398 significantly enhanced the 5-FU cytotoxicity after 48-hour treatment ( $35 \%$ and $38 \%$ vs. 5-FU, respectively) [8]. It is noteworthy, however, that in HT29-C cells, characterized by enhanced COX-2 and DPD expressions, the potentiation of 5-FU action could be achieved already after 8-hour treatment compared to the constitutively high COX-2 and DPD expressing HCA-7 cells where 48 hours were necessary to obtain a significant 5-FU cytotoxic effect. 
Influence of indomethacin or NS-398 on DPD mRNA expression and enzyme activity in HT29-C and HCA-7 cells

We have examined whether treatment of HT-29-C and HCA-7 cells with 5-FU and its combination with NSAIDs regulates the DPYD mRNA expression and enzyme activity one of the most important determinant of 5-FU action. In HT-29-C cells the DPYD mRNA expression was significantly decreased by 5-FU treatment $(\mathrm{p}<0.01)$. This effect was potentiated by combining 5-FU with NSAIDs ( $<<0.05$ vs 5 -FU).

In case of HCA-7 cells, however, the DPYD mRNA expression was reduced in a nonsignificant manner, but when 5-FU was combined with indomethacin or NS-398 the decrease was significant compared to 5 -FU treatment ( $p<0.05$ vs 5 -FU). No differences between the enhancing effect of indomethacin and NS-398 could be found (Table 2). The decrease of DPD enzyme activity was non-significant in both cell lines after 5-FU treatment, while at the same time indomethacin or NS-398 potentiated significantly the enzyme inhibitory effect of 5-FU. (Table. 2)

Influence of indomethacin or NS-398 on the tumor growth inhibitory effect of 5-FU in HT-29 xenografts

The mice tolerated well the administration of 6 and $30 \mathrm{mg} / \mathrm{kg} / \mathrm{day} 5-\mathrm{FU}$ or their combinations with $2.5 \mathrm{mg} / \mathrm{kg} /$ day indomethacin or $5 \mathrm{mg} / \mathrm{kg} /$ day $\mathrm{NS}-398$, as well.

In HT-29 xenografts $6 \mathrm{mg} / \mathrm{kg}$ 5-FU did not affect the tumor growth compared to the control, but the simultaneous treatment with indomethacin or NS-398 potentiated significantly the tumor growth inhibitory effect of 5-FU (33.3\% and $42 \%$ decrease vs 5-FU). The tumor growth inhibitory potential of $6 \mathrm{mg} / \mathrm{kg} 5-\mathrm{FU}+$ NSAIDs was similar to that obtained by 30 $\mathrm{mg} / \mathrm{kg} 5$-FU monotherapy, which decreased the relative tumor growth by $\sim 50 \%(\mathrm{p}<0.001)$ compared to the control, but it is noteworthy that NSAIDs could not further enhance the cytotoxic effect of $30 \mathrm{mg} / \mathrm{kg}$ 5-FU (Fig. 3). Neither indomethacin, nor NS-398 alone 
influenced significantly the tumor growth of HT-29 xenografts after 5-day treatment (data not shown).

Effect of 5-FU \pm NSAIDs on DPD enzyme activity in HT-29 xenografts

5-fluorouracil (6 mg/kg/day) caused a significant decrease of DPD enzyme activity compared to the control and this enzyme inhibitory effect was potentiated significantly by INDO or NS398 ( $\mathrm{p}<0.05$ and $\mathrm{p}<0.01$, respectively) compared to 5-FU treatment. Noteworthy, that the decrease in DPD activity caused by the $6 \mathrm{mg} / \mathrm{kg} 5$-FU+NSAIDs was similar to that obtained after treatment with $30 \mathrm{mg} / \mathrm{kg}$ 5-FU alone (Fig. 4). Similarly to the in vitro results the DPD suppressing effect of indomethacin or NS-398 was about the same.

\section{Evaluation of drug interaction between 5-FU and NSAIDs}

To investigate the therapeutic advantage of the potentiation of 5-FU cytotoxicity by NSAIDs the drug interaction analysis was performed. The type of interaction between 5-FU and indomethacin or NS-398 in HT-29-C cells was synergistic (R:1.57 and 1.71, respectively) compared to HT-29 cells in which it was only additive. A remarkable synergy was achieved also in case of HT-29 xenografts after treatment with $6 \mathrm{mg} / \mathrm{kg} 5$-FU combined with the two NSAIDs (R:1.48 and 1.47, respectively) (Table 3).

\section{Discussion}

Cyclooxygenase-2 expression was described in several tumor types including colorectal, gastric, esophageal, hepatocellular, breast etc. cancers and its overexpression is often associated with a shorter time to progression or overall survival [5]. The cyclooxygenase enzymes are the best characterized targets of NSAIDs, which inhibit their activity. Recently, there has been much interest in using COX-2 inhibitors along with conventional anticancer 
therapy [15]. Previously, it was demonstrated that in high COX-2 expressing cell lines NSAIDs in addition to COX-2 inhibition also reduced the DPD enzyme activity [9].

In the present study high COX-2-expressing colorectal cancer cell lines and xenograft were used to demonstrate the enhancement of 5-FU cytotoxicity induced by the NSAIDs-related inhibition of DPD mRNA level and enzyme activity.

The results of the present study regarding the induction of COX-2 by collagen IV are in accordance with the findings demonstrated that various ECM proteins induced COX-2 expression in HUVEC cells [16]. Collagen I and IV mediated expression of COX-2 was also described in epithelial cells [17]. Until now, direct association between DPD expression and signals induced by ECM components could not be found in the literature. In 3D collagen I gel cultures the Sp1 transcription factor was increased in HSC cells [18]. Zhang et al. demonstrated that the Sp1 binds to the DPYD promoter and acts as a potent transactivator [19]. Based on these data, one can speculate that collagen could affect the DPD expression via Sp1. On the other hand, NSAIDs activate proteosome-dependent degradation of Sp1 [20]. In this study NSAIDs enhanced the cytotoxicity effect of 5-FU in vitro and in vivo, as well. Many studies proved that NSAIDs potentiated the effect of conventional chemotherapeutic drugs such as 5-FU, cisplatin, oxaliplatin, S-1 etc [21-23]. However, there are only few investigations presenting the effect of 5-FU combined with low dose NSAIDs on cancer cells or xenografts. Low dose indomethacin significantly reduced the $\mathrm{IC}_{50}$ of 5-FU treatment on COX-2-expressing murine Colon 26 cells [21]. Similarly, SKG-2 and HKUS human cervical cancer cells after treatment with indomethacin showed significantly increased 5-FU cytotoxicity [24]. An impressive but interestingly non-significant tumor volume decrease (40\%) after 28-day low dose ibuprofen+5-FU treatment in a COX-2-expressing mouse colorectal tumor modell was described [25]. 
On the other hand, NS-398 at low dose protected HeLa cells against the cytotoxic action of cisplatin, paclitaxel and 5-FU [26]. It is worth mentioning, that Shestopal et al demonstrated that HeLa cells showed the lowest DPD mRNA level among five investigated cell lines [27]. The selective COX-2 inhibitor, JTE-522, synergistically enhanced the cytotoxic effect of 5FU against COX-2 expressing bladder cancer cells, T24 and HT1197 [28]. Triptolide, which among others showed COX-2-inhibitory effect too, at low concentration presented synergistic effect with 5-FU on the growth of HT-29 colon carcinoma in vitro and in vivo [29]. Interestingly, in COX-2 expressing LM-H3 colon cancer cells the effect of 5-FU was enhanced by the DPD inhibitor, 5-chloro-2,4-dihydroxypyridine (CDHP). Etodolac and rofecoxib did not increase the cytotoxic effect of 5-FU, however, the combination of S-1 + NSAIDs inhibited the liver metastasis formation compared to S-1 after tumor cell inoculation in the mice spleen [22]. Low dose of nitric oxide-donating NSAID, NCX 4040, enhanced 5FU cytotoxicity on colon adenocarcinoma cell lines, but not xenografts [23]. Their findings on cell lines are in accordance with the results of the present study, while the discrepant results regarding the xenografts may be due to the different treatment schedules and applied 5-FU doses.

Combination of 5-FU with various modulators e.g. DPD inhibitors, resulted in an increased antitumor effect and enhanced rate of apoptosis [3, 4, 30].

The present study is one of the first, which demonstrates that the NSAIDs caused decrease of DPD activity caused by NSAIDs enhanced the 5-FU cytotoxicity. Although, the DPD enzyme activity in connection with 5-FU action has been in limelight, up to this day there are few data about the DPD regulation, although, growing evidence has been accumulated that not only the well-known DPD inhibitors are able to modulate the DPD enzyme activity e.g TRAIL, IFN [31, 32]. A very recent article described synergistic effect of 5-FU and a bioactive flavonoid, oroxylin A in vitro and in vivo. The combined treatment significantly decreased the DPYD 
mRNA levels compared to 5-FU alone. In addition, oroxylin A among other effects inhibits the lipopolysaccharide- induced COX-2 expression [33].

DPD activity has previously been reported to correlate with its prote in level in human lymphocytes [34] and with mRNA levels in colorectal tumors and liver tissues [35]. In the present study a similar correlation was found in vitro between DPD enzyme activity and the mRNA expression. On the other hand, others did not find any correlation between DPD enzyme activity, protein level and mRNA expression [36]. The discrepancy might be due to the non-comparable methods used in different studies.

It is worth mentioning that in our study 5-FU alone caused a decrease in DPD enzyme activity both in vitro and in vivo. Literature data concerning the effect of 5-FU exposure on DPD levels are not conclusive [37-39] thus further investigations are needed to clarify in details these findings.

Although, it is well known that 5-FU resistance is multifactorial the DPD status is among the most important predictors of 5-FU efficacy in vitro, in vivo and in clinical practice, as well. The sensitivity of 4 gastric and 3 colorectal cancer cell lines to 5 -FU were in inverse correlation with DPD protein or mRNA levels [40]. A significant correlation was found between DPYD DNA copy number and mRNA or enzyme activity in 58 human cancer cell lines and 31 human cancer xenografts. In cell lines the 5-FU sensitivity was significantly correlated with DPYD copy number, which also differed significantly between drug-resistant and drug-sensitive xenografts [41]. The prognostic value of DPD enzyme activity [42] or mRNA level [43] was demonstrated in patiens with colorectal cancer treated with 5-FU-based chemotherapy.

In the present study the indomethacin and NS-398 caused downregulation of DPYD mRNA expression and consequently the reduction of the enzyme activity in expreimental systems was in good relationship with the enhancement of the antiproliferative potency of 5-FU. 
Finally, based on our results it is possible to conclude that 5-FU efficacy could be limited by the COX-2 associated high DPD expression and activity in patients with colorectal cancers as well, therefore further clinical studies are varraned to decide if NSAIDs in the therapeutic protocol might inprove the antitumor potency of 5-FU.

\section{Acknowledge ments}

The SCID mice were generously gifted by Dr. D. Gaál. The excellent technical assistance of Cs. Polényi Makácsné, A. Nagy, J. Kútvölgyi, A. Éber Mousáné, A. Sztodola and A. M. Borza were greatly appreciated.

This study was supported by the Jedlik Ányos Grant (NKFP1-00024/2005). 
Table 1. Comparison of cyclooxygenase- 2 and dihydropyrimidine dehydrogenase status of uninduced HT-29 and collagen-ind uced HT-29-C cells

\begin{tabular}{|c|c|c|}
\hline & HT-29 & HT-29-C \\
\hline $\begin{array}{l}\text { DPD enzyme activity (pmol/min/mg } \\
\text { protein) }\end{array}$ & $9 \pm 2.7$ & $17.44 \pm 2.87^{\#}$ \\
\hline $\mathrm{PGE}_{2}$ level (pg/ml) & ND & $50.85 \pm 12.3^{\#}$ \\
\hline Relative $D P Y D$ mRNA expression ${ }^{\mathrm{a}}$ & $8.09 \pm 0.4 \times 10^{-3}$ & $2328 \pm 464 \times 10^{-3} \#$ \\
\hline Relative $C O X-2$ mRNA expression ${ }^{\mathrm{a}}$ & $4.8 \pm 1.4 \times 10^{-6}$ & $\begin{array}{c}3624 \pm 1221 \times 10^{-6} \\
\#\end{array}$ \\
\hline
\end{tabular}

${ }^{\mathrm{a}}$ related to $\beta$-actin $\mathrm{mRNA} ;{ }^{\#} \mathrm{p}<0.05$ vs. uninduced cells; ND: non-detectable; 
Table 2. Change of dihydropyrimidine dehydrogenase status after the treatment with $5-\mathrm{FU} \pm$ indomethacin or NS-398 in collagen-induced HT-29 (HT-29-C) and HCA-7 cells

\begin{tabular}{|l|c|c|c|c|}
\hline & \multicolumn{2}{|c|}{ HT-29-C cells } & \multicolumn{2}{c|}{ HCA-7 cells } \\
& mRNA & enzyme activity & mRNA & enzyme activity $^{\mathrm{b}}$ \\
& expression $^{\mathrm{a}}$ & & expression $^{\mathrm{a}}$ & \\
\hline control & $2.3 \pm 0.5$ & $17.4 \pm 2.9$ & $10.4 \pm 3.7$ & $99.6 \pm 13.1$ \\
\hline 5-FU & $0.9 \pm 0.08^{*}$ & $14.6 \pm 3.6$ & $9.6 \pm 1.4$ & $90.2 \pm 1.7$ \\
\hline 5-FU+ & $0.06 \pm 0.04^{\#}$ & $5.1 \pm 1.6^{\#}$ & $1.2 \pm 0.4^{\#}$ & $54.3 \pm 7.6^{\#}$ \\
indomethacin & & & & \\
\hline 5-FU+ NS-398 & $0.005 \pm 0.004^{\#}$ & $5.9 \pm 1.1^{\#}$ & $0.6 \pm 0.07^{\#}$ & $55.0 \pm 6.3^{\#}$ \\
\hline
\end{tabular}

HT-29 cells were incubated with $10 \mu \mathrm{M}$ 5-FU alone or combined with either $10 \mu \mathrm{M}$ indomethacin or $1.77 \mu \mathrm{M}$ NS-398; HCA-7 cells were incubated with $1 \mathrm{mM} 5$-FU alone or combined with either $10 \mu \mathrm{M}$ indomethacin or $1.77 \mu \mathrm{M} N S-398:^{\text {a }}$ related to $\beta$-actin mRNA; ${ }^{b}$ $\mathrm{pmol} / \mathrm{min} / \mathrm{mg}$ protein, ${ }^{*} \mathrm{p}<0.01$ vs control; ${ }^{\#} \mathrm{p}<0.05$ vs $5-\mathrm{FU}$ 
Table 3. Drug interaction between 5-FU and indomethacin or NS-398

\begin{tabular}{|l|c|c|}
\hline & $\mathrm{R}_{\mathrm{INDO}}{ }^{\mathrm{a}}$ & $\mathrm{R}_{\mathrm{NS}-398^{\mathrm{a}}}$ \\
\hline HT-29 cells & 1.02 & 1.09 \\
\hline HT-29-C cells & 1.57 & 1.71 \\
\hline HT-29 xenograft $6 \mathrm{mg} / \mathrm{kg} \mathrm{5-}$ & 1.48 & 1.47 \\
\hline HU & & \\
FU & 1.19 & 1.13 \\
\hline
\end{tabular}

${ }^{a}$ Type of interaction $\mathrm{R}=1$, additive effect; $>1$, synergistic effect; $<1$, antagonistic effect. The synergistic ratio $R$, was calculated as: $R=S_{\text {exp }} / S_{\text {obs }}$ 


\section{Legend of figures}

Fig 1 Representative immunofluorescent staining of COX-2 in HT-29 (a) and collageninduced HT-29-C cells (b), and DPD proteins in HT-29 (c) and collagen-induced HT-29-C cells (d) ( x 250)

Fig 2 Cell growth inhibition of HT-29 (a), collagen-induced HT-29 (HT-29-C) (b) cells after treatment with $10 \mu \mathrm{M} 5$-FU (open bars), $10 \mu \mathrm{M}$ 5-FU+10 $\mu \mathrm{M}$ indomethacin (gray bars) and $10 \mu \mathrm{M}$ 5-FU+1.77 $\mu \mathrm{M}$ NS-398 (black bars) measured by sulphorhodamine B assay. Each bar represents the mean+SD of six independent experiments in percent of control. ${ }^{\#} \mathrm{p}<0.05$ vs 5 FU

Fig 3 Inhibitory effect of 5-FU (open bar), 5-FU+indomethacin (gray bar) or 5-FU+NS-398 (black bar) treatment on the tumor growth of HT-29 xenografts determined by the change of relative tumor volume growth (RTG).

(a) $6 \mathrm{mg} / \mathrm{kg} / \mathrm{day}$ and (b) $30 \mathrm{mg} / \mathrm{kg} /$ day 5 -FU; ${ }^{*} \mathrm{p}<0.001$ vs control, ${ }^{\#} \mathrm{p}<0.05$ vs 5 -FU, \# $\mathrm{p}<0.001$ vs $5-\mathrm{FU}$

Fig 4 Inhibitory effect 5-FU (open bar) 5-FU + indomethacin (gray bar) and 5-FU+NS-398 (black bar) treatment on the DPD enzyme activity (pmol/min/mg protein) of HT-29 xenografts.(a) $6 \mathrm{mg} / \mathrm{kg} / \mathrm{day}$ and (b) $30 \mathrm{mg} / \mathrm{kg} /$ day $5-\mathrm{FU} ;{ }^{*} \mathrm{p}<0.001$ vs control, ${ }^{\#} \mathrm{p}<0.05$ vs 5FU, ${ }^{\# \#} \mathrm{p}<0.01$ vs $5-\mathrm{FU}$ 


\section{References}

1. Schnackerz KD, Dobritzsch D, Lindqvist Y, Cook PF (2004) Dihydropyrimidine dehydrogenase: a flavoprotein with four iron-sulfur clusters. Biochim Biophys Acta 1701:6174

2. Hoff PM (2000) The tegafur-based dihydropyrimidine dehydrogenase inhibitory fluoropyrimidines, UFT/leucovorin $\left(\mathrm{ORZEL}^{\mathrm{TM}}\right)$ and $\mathrm{S}-1$ : a review of their clinical development and therapeutic potential. Invest New Drugs 18:331-342

3. Ahmed FY, Johnston SJ, Cassidy J et al (1999) Eniluracil treatment completely inactivates dihydropyrimidine dehydrogenase in colorectal tumors. J Clin Oncol 17:2439-2445

4. Kralovánszky J, Katona C, Jeney A et al (1999) 5-Ethyl-2'-deoxyuridine, a modulator of both antitumour action and pharmacokinetics of 5-fluorouracil. J Cancer Res Clin Oncol $125: 675-684$

5. de Groot DJ, de Vries EG, Groen HJ, de Jong S (2007) Non-steroidal anti-inflammatory drugs to potentiate chemotherapy effects: from lab to clinic. Crit Rev Oncol Hematol 61:5269

6. Bennett A, Gaffen JD, Melhuish PB, Stamford IF (1987) Studies on the mechanism by which indomethacin increases the anticancer effect of methotrexate. Br J Pharmacol 91:229235

7. Totzke G, Schulze-Osthoff K and Jänicke U (2003) Cyclooxygenase-2 (COX-2) inhibitors sensitize tumor cells specifically to death receptor-induced appoptosis independently of COX2 inhibition. Oncogene 22:8021-8030

8. Réti A, Barna G, Pap E, Adleff V, L Komlósi V, Jeney A, Kralovánszky J, Budai B (2008) Enhancement of 5-Fluorouracil Efficacy on High COX-2 Expressing HCA-7 Cells by LowDose Indomethacin and NS-398 but not on Low COX-2 Expressing HT-29 Cells. Pathol Oncol Res. doi 10.1007/s12253-008-9126-9 
9. Reti A, Pap É, Zalatnai A, Jeney A, Kralovanszky J, Budai B: Co-inhibition of Cyclooxygenase-2 and Dihydropyrimidine Dehydrogenase by Non-steroidal Antiinflammatory Drugs in Tumor Cells and Xenografts (2009) Anticancer Res 29:3095-3102 10. Pfaffl MW (2001) A new mathematical model for relative quantification in real-time RTPCR. Nucleic Acids Res 29:e45

11. Guichard S, Cussac D, Hennebelle I, Bugat R, Canal P (1997) Sequence-dependent activity of the irinotecan-5FU combination in human colon-cancer model HT-29 in vitro and in vivo. Int J Cancer 73:729-734

12. Eli Y, Przedecki F, Levin G, Kariv N, Raz A (2001) Comparative effects of indomethacin on cell proliferation and cell cycle progression in tumor cells grown in vitro and in vivo. Biochem Pharmacol 61:565-571

13. Muneaki Matsuo, Nobuyuki Yoshida, Masahumi Zaitsu, Kiyohisa Ishii and Yuhei Hamasaki (2004) Inhibition of human glioma cell growth by a PHS-2 inhibitor, NS398, and a prostaglandin E receptor subtype EP1-selective antagonist, SC51089. Journal of NeuroOncology 66: 285-292

14. Kern DH, Morgan CR, Hildebrand-Zanki SU (1988) In vitro pharmacodynamics of 1beta-D-arabinofuranosylcytosine: synergy of antitumor activity with cis-diamminedichloroplatinum(II). Cancer Res 48:117-121

15. Sweeney CJ (2003) Why cyclooxygenase-2 inhibition plus chemotherapy? Am J Clin Oncol 26: S122-125

16. Zaric J, Rüegg C (2005) Integrin-mediated adhesion and soluble ligand binding stabilize COX-2 protein levels in endothelial cells by inducing expression and preventing degradation.

J Biol Chem. 280:1077-1085

17. Broom OJ, Massoumi R, Sjölander A (2006) Alpha2beta1 integrin signalling enhances cyclooxygenase-2 expression in intestinal epithelial cells. J Cell Physiol 209:950-958 
18. Takahra T, Smart DE, Oakley F, Mann DA (2004) Induction of myofibroblast MMP-9 transcription in three-dimensional collagen I gel cultures: regulation by NF-kappaB, AP-1 and Sp1. Int J Biochem Cell Biol 36:353-363

19. Zhang X, Li L, Fourie J, Davie JR, Guarcello V, Diasio RB (2006) The role of Sp1 and Sp3 in the constitutive DPYD gene expression. Biochim Biophys Acta 1759:247-256

20. Abdelrahim M, Safe S (2005) Cyclooxygenase-2 inhibitors decrease vascular endothelial growth factor expression in colon cancer cells by enhanced degradation of Sp1 and Sp4 proteins. Mol Pharmacol 68:317-329

21. Ogino M, Hanazono M (1999) Indomethacin preferentially augments 5-fluorouracil cytotoxicity in Colon 26 tumors by increasing the intracellular inflow of 5-fluorouracil. Int $\mathbf{J}$ Clin Oncol 4:22-25

22. Tachimori A, Yamada N, Amano R, Ohira M, Hirakawa K (2008) Combination the rapy of S-1 with selective cyclooxygenase-2 inhibitor for liver metastasis of colorectal carcinoma. Anticancer Res 28:629-638

23. Leonetti C, Scarsella M, Zupi G et al (2006) Efficacy of a nitric oxide-releasing nonsteroidal anti-inflammatory drug and cytotoxic drugs in human colon cancer cell lines in vitro and xenografts. Mol Cancer Ther 5:919-926

24. Ogino M, Minoura S (2001) Indomethacin increases the cytotoxicity of cis-platinum and 5-fluorouracil in the human uterine cervical cancer cell lines SKG-2 and HKUS by increasing the intracellular uptake of the agents. Int J Clin Oncol 6:84-89

25. Yao M, Zhou W, Sangha S, Albert A, Chang AJ, Liu TC, Wolfe MM (2005) Effects of nonselective cyclooxygenase inhibition with low-dose ibuprofen on tumor growth, angiogenesis, metastasis, and survival in a mouse model of colorectal cancer. Clin Cancer Res 11:1618-1628 
26. Eichele K, Ramer R, Hinz B (2008) Decisive role of cyclooxygenase-2 and lipocalin-type prostaglandin D synthase in chemotherapeutics-induced apoptosis of human cervical carcinoma cells. Oncogene 27:3032-3044

27. Shestopal S A, Johnson MR, Diasio RB. (2000) Molecular cloning and characterization of the human dihydropyrimidine dehydrogenase promoter. Biochim Biophys Acta 1494:162-169 28. Mizutani Y, Kamoi K, Ukimura O, Kawauchi A, Miki T (2002) Synergistic cytotoxicity and apoptosis of JTE-522, a selective cyclooxygenase-2 inhibitor, and 5-fluorouracil against bladder cancer. J Urol 168:2650-2654

29. Tang XY, Zhu YQ, Tao WH, Wei B, Lin XL (2007) Synergistic effect of triptolide combined with 5-fluorouracil on colon carcinoma. Postgrad Med J 83:338-343

30. Adeyemo D, Imtiaz F, Toffa S, Lowdell M, Wickremasinghe RG, Winslet M (2001) Antioxidants enhance the susceptibility of colon carcinoma cells to 5-fluorouracil by augmenting the induction of the bax protein. Cancer Lett 164:77-84

31. Mizutani Y, Nakanishi H, Yoshida O, Fukushima M, Bonavida B, Miki T (2002) Potentiation of the sensitivity of renal cell carcinoma cells to TRAIL-mediated apoptosis by subtoxic concentrations of 5-fluorouracil. Eur J Cancer 38:167-176

32. Dou J, Iwashita Y, Sasaki A, Kai S, Hirano S, Ohta M, Kitano S (2005) Consensus interferon enhances the anti-proliferative effect of 5-fluorouracil on human hepatoma cells via downregulation of dihydropyrimidine dehydrogenase expression. Liver Int 25:148-152

33. Zhao L, Chen Z, Wang J et al (2009) Synergistic effect of 5-fluorouracil and flavonoid oroxylin A on HepG2 human hepatocellular carcinoma and on $\mathrm{H}_{22}$ transplanted mice. Cancer Chemother Pharmacol doi 10.1007/s00280-009-1053-2

34. Takechi T, Okabe H, Fujioka A, Murakami Y, Fukushima M (1998) Relationship between protein levels and gene expression of dihydropyrimidine dehydrogenase in human tumor cells during growth in culture and in nude mice. Jpn J Cancer Res 89:1144-1153 
35. Johnson MR, Wang K, Smith JB, Heslin MJ, Diasio RB (2000) Quantitation of dihydropyrimidine dehydrogenase expression by real-time reverse transcription polymerase chain reaction. Anal Biochem 278:175-184

36. Miyamoto S, Ochiai A, Boku N, Ohtsu A, Tahara M, Yoshida S, Okabe H, Takechi T, Fukushima M (2001) Discrepancies between the gene expression, protein expression, and enzymatic activity of thymidylate synthase and dihydropyrimidine dehydrogenase in human gastrointestinal cancers and adjacent normal mucosa. Int J Oncol 18:705-713

37. Nishiyama M, Yamamoto W, Park JS et al (1999) Low-dose cisplatin and 5-fluorouracil in combination can repress increased gene expression of cellular resistance determinants to themselves. Clin Cancer Res 5:2620-2628

38. Sakurai Y, Uraguchi T, Imazu H, Hasegawa S, Matsubara T, Ochiai M, Funabiki T (2004) Changes in thymidylate synthase and its inhibition rate and changes in dihydropyrimidine dehydrogenase after the administration of 5-fluorouracil with cisplatin to nude mice with gastric cancer xenograft SC-1-NU. Gastric Cancer 7:110-116

39. Sakurai Y, Yoshida I, Kamoshida S, Inaba K, Isogaki J, Komori Y, Uyama I, Tsutsumi Y (2008) Changes of gene expression of thymidine phosphorylase, thymidylate synthase, dihydropyrimidine dehydrogenase after the administration of 5'-deoxy-5-fluorouridine, paclitaxel and its combination in human gastric cancer xenografts. Anticancer Res 28:15931602

40. Ma T, Zhu ZG, Ji YB, Zhang Y, Yu YY, Liu BY, Yin HR, Lin YZ (2004) Correlation of thymidylate synthase, thymidine phosphorylase and dihydropyrimidine dehydrogenase with sensitivity of gastrointestinal cancer cells to 5-fluorouracil and 5-fluoro-2'-deoxyuridine. World J Gastroenterol 10:172-176

41. Kobunai T, Ooyama A, Sasaki S, Wierzba K, Takechi T, Fukushima M, Watanabe T, Nagawa H (2007) Changes to the dihydropyrimidine dehydrogenase gene copy number 
influence the susceptibility of cancers to 5-FU-based drugs: Data mining of the NCI-DTP data sets and validation with human tumour xenografts. Eur J Cancer 43:791-798

42. Kralovánszky J, Adleff V, Hitre E, Pap E, Réti A, Komlósi V, Budai B (2007) Pharmacogenetic studies on the prediction of efficacy and toxicity of fluoropyrimidine-based adjuvant therapy in colorectal cancer. Magy Onkol 51:113-125

43. Yamada H, Iinuma H, Watanabe T (2008) Prognostic value of 5-fluorouracil metabolic enzyme genes in Dukes' stage B and C colorectal cancer patients treated with oral5fluorouracil-based adjuvant chemotherapy. Oncol Rep 19:729-735 
a
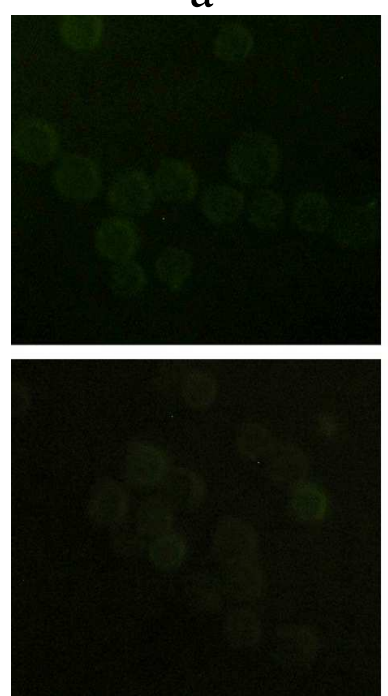

c $\mathrm{b}$

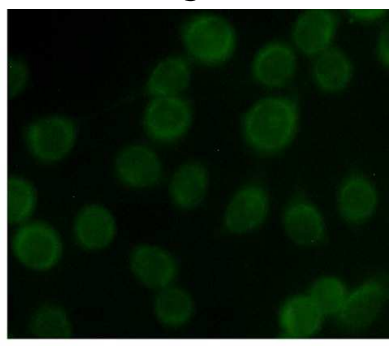

d 

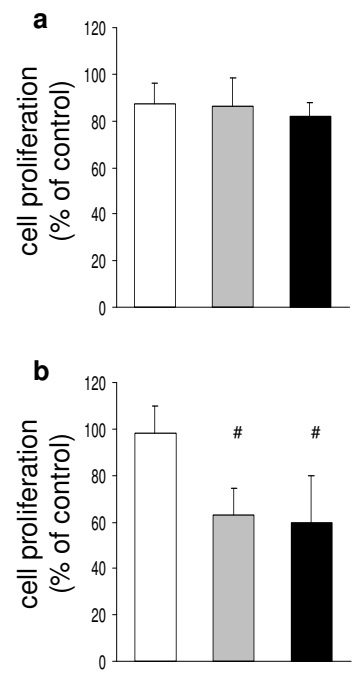


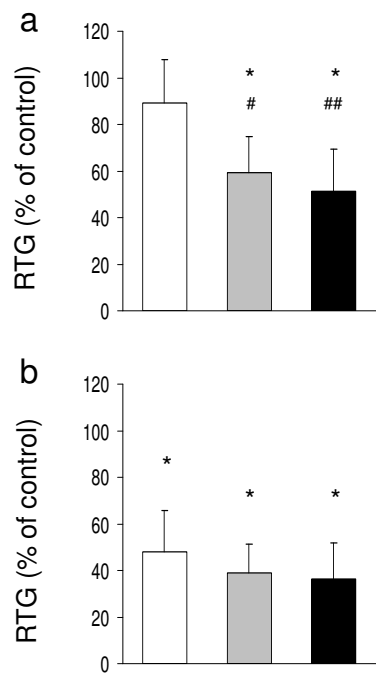


DPD enzyme activity after 6-days DPD enzyme activity after 6-days treatment (\% of control) $\quad \sigma \quad$ treatment (\% of control)

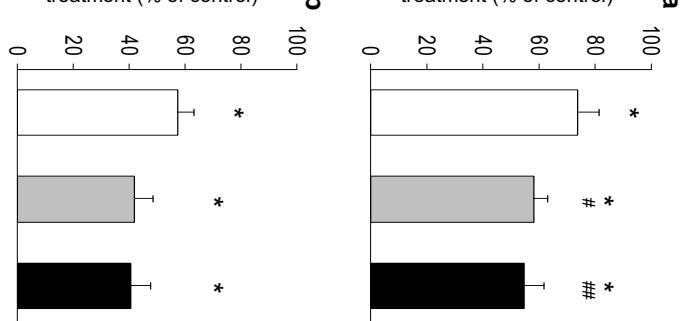

